\title{
THE IMPACT OF THE 19TH CENTURY EUROPEAN COLONIALISM IN AFRICA, IN THE NOVEL "THINGS FALL APART" BY CHINUA ACHEBE
}

\author{
Afriliyani Piola ${ }^{1}$ \\ Happy Anastasia Usman ${ }^{2}$ \\ English Literature Department, University of Muhammadiyah Gorontalo \\ Afriliyanipiola@gmail.com
}

\begin{abstract}
Things Fall Apart is a novel potrays the background of traditional life and primitive culture Ibo tribe in Umuofia, Nigeria, Africa and also the impact of European colonialism towards Africans' society in the early 19th century. The research applies the qualitative method and it supported by the sociology of literature approach. The primary data are taken from the novel Things Fall Apart by Chinua Achebe. Based on the analysis the researcher conducts, the impact of European colonialism in Africa which not only brings a positive impacts but also negative legacy. There are several points of the impact European colonialism in Africa : existence of christianity, existence of language, establishment regulation and contribution to development.
\end{abstract}

Keywords: Impact, Africa, Positive And Negative of Colonialism

\section{INTRODUCTION}

Literature is more focuses and restricted to merely imaginative works, which comes up from the imaginative mind of the story writers. Literature is most often refers to the creative imagination, written or fiction like a novel, poetry, and songs. While the nonfiction drama, movies, news and etc. Fiction is author's imagination which enlighten the truth relations between people and their life (Altenbernd and Lewis in Nurgiyantoro, 2005).

According to Abrams in Nurgiyantoro (2009: 9) states the term novel comes from the italian word "novella" containing literal meaning a small new stuff, which are interpreted as a short story in prose. Novel has strong relation with the real life of human being through its story. It sees that basically, novel comes from author's imagination which influenced by people's life and totally expressed in written form. In understand literary works relates to society or even the social elements containe in literature, an approach or review is requires namely sociology of literature.

According to Saryono (2009: 18) states that literature also has the ability to record all empirical experience-natural or supernatural nonempiris-experience, in other words a literature capable of being witnesses of the commenter in human life. In the

British, Jurnal Bahasa dan Sastra Inggris

Volume 8. No 2. September 2019 
novel Things Fall Apart tells about the human life of Ibo tribe who its classy people and they still primitive and marginal, encouraging the white colonial British Europe with its more modern civilization to expand its imperial territory and colonial hegemony in Africa. The colonization and cultural imperialism programs is proclaime slowly and gradually by British white colonialists. With the motive and pretext of civilizing the traditional primitive life of the Ibo tribe, British colonialists who have the interests of colonial hegemony occupies indigenous African lands through a very subtle, clever and peaceful colonial strategy.

Literature has three general genres, they are Drama, Poetry, and Prose. The word 'drama' is derived from the Greek word 'dran' means 'to do' or 'to act'. Poetry is created in various forms and the classification is based either on technique of writing or content. The word 'prose' is derived from the Latin prosa, which literally translates to 'straightforward'. Prose is the ordinary form of written language. Prose is adopted for the discussion of facts and topical reading, as it is often articulated in free form the writes style.

Sociology Of Literature Is An Understand Of Literary Works With Consider Social Aspects (Ratna: (2003). Sociology of literature is analysis as a objective and scientific which study about humans in a society that deals with social and social processes. . This research is in great demand by researchers who want to see literature as a mirror of society's live (Suwardi, 2008).

Colonialism is the direct and overall domination of one country by another on the basis of state power being in the hands of a foreign power (For example, the direct and overall domination of Nigeria by Britain between 1900-1960 (Stephen Ocheni and Basil C. Nwankwo: 2012).

The background of Britain comes to Africa is to implement an indirect rule system that aims to guide the population along with the indigenous rulers to achieve self-government status by using the elements of society that are popular and respects by the population. Based on this system, the function of the British government is not to destroy the culture and institutions of the indigenous population, but even to maintain positive elements, then to be combines them with elements based on Western ideas. Like other colonized countries, Britain demands its colonies to fill the neccesity of the political, economic and moral needs of the metropolitan country. 
European colonialism that occurs in Africa can be seen as a positive inheritance or a negative legacy. According to Khapoya $(2009,135-136)$ explains that there are four forms of positive colonialism. First is the introduction of western medicine technology that improves the health of African society and increases the life expectancy of African society, second is formal education, third is the legacy of western infrastructure And inherites religious heritage can be used as a spiritual basis for African society.

However, in the legacy of colonialism in negative connotations has a negative impact (Khapoya: 2009). First is the massive exploitation of natural resources, unfair taxation system, weak industry, dependence on a resource as an economic pillar. Second is the ethnic conflicts that occur in Africa is a sheepfighting which form in the era of colonialism, like Britain which makes the colonial policy "indirect rule". Third is traditional African culture replaces by European methods of development that make travel difficult which results in tradition mismatch. Fourth, the division of territories carried by the Europeans increases the conflict over territory. Finally, Western cultures integrates during the colonialism era replaces traditional values of African society.

It concludes that the legacy of colonialism can have a positive but also negative impact. Where the invaders when colonize an area can leave the advances in science and technology from Europe. For examples include the development of medical science or also strong western infrastructure. But on the other hand, the mechanics and systems used by colonizers in a colony are inheritances that have a negative impact on people's lives both during colonialism and after colonialism where the habits or characteristics of the new colonial system will disappear for several years.

In this research, the researcher analyze the impact of European colonialism in Africa, 19th century in the novel "Things Fall Apart" by Chinua Achebe by sociology of literature approach. The researcher applies the qualitative method in analyzed the novel. The analyze the impact of the 19th century European colonialism in Africa. European colonialism in africa brings a positive impact such as : Religious can be used as a spiritual basis for African society, build a school for education of Africans' children, hospital for a better healt of Africans' society as well as in economic field, European build a markets. But on the other hand, the mechanics and systems uses by European also brings a negative impact such as : language where European uses english

\section{British, Jurnal Bahasa dan Sastra Inggris \\ Volume 8. No 2. September 2019}


in colonialiasm that can impact to the langauge which exist in African which is Ibo language.

\section{METHOD OF RESEARCH}

This study uses qualitative methods, according to Blaxter (1996: 61) qualitative research is concern with collecting and analyzing information in as many forms . This qualitative method is the method that used to analyzed, which are explaining and narrate the data in words of paragraphs. In this research uses library research to collect the data. According to Daniel A.R ( 2009: 80) Library research is a research conducted by researchers by collecting aseveral books, magazines, leaflets relating to the problem and research objectives. The research use Library research in this research which most of the data obtain from the novel, ensyclopedia, essay, journal, article, magazine, and the onthers that purposes as references to support this research. In this research, the researcher also applies the sociology of literature especialy in analyzing the impact of European colonialism in Africa, 19th century in the novel "Things Fall Apart" by Chinua Achebe. According to Damono, (2003:2-10) states that if the literature is associated with social structure, kinship relations, class conflict, etc it can be use sociology of literature.

\section{RESULT AND DISCUSSION}

\section{Positive Impact of European colonialism in Africa}

European colonialism in Africa has several forms of positive colonialism. First is the introduction of western medicine technology that improves the health of African society and increases the life expectancy of African society. Second is formal education implements by Europeans in Africa to increase the knowledge of African society which then also triggers the African community's rebellion against western colonialism. Third is the legacy of western infrastructure in the colonialism era that can be develops to build more sophisticate infrastructures by study these infrastructure and rebuilding them. Finally, inherites religious heritage can be uses as a spiritual basis for African society.

\section{Existence of Christianity}

The arrival of missionaries in Africa bring christianity as religion in Africa, they efforts build a church in the existence of christianity religious in Umuofia. In addition, British, Jurnal Bahasa dan Sastra Inggris 
they got a rejections from the villagers but at the end they can prove that christianity is a religion in Umuofia begins to accepts by the villagers, the impact is many of villagers decides to become an adherent of christianity and even become a convert.

Data 01:

"The missionaries had come to Umuofia. They had built their church there, won a handful of converts and were already sending evangelists to the surrounding towns and villages". (Achebe, 1958: pg 51)

In the data 01 the finding shows that the existence of christianity as Religion in Umuofia begins to be accepted by the villagers. Although, they got a rejections from the villagers in their first arrival but at the end they can build a church in Umuofia and they even got many villagers to becomes a convert. In fact, European colonize africa by religion because religion is a smooth and peaceable ways to civilize Africa (Khapoya, 2009).

Data 02:

"The missionaries spent their first four or five nights in the marketplace, and went into the village in the morning to preach the gospel" ". (Achebe, 1958: pg 53)

In the finding of data 02 concludes they use Gospel as their effort to practices christianity as religious in Umuofia, the misionaries usually give a speech around the village by using Gospel as the basis of christianity.

Data 03:

"The Christians had grown in number and were now a small community of men, women and children, self-assured and confident. Mr. Brown, the white missionary, paid regular visits to them. "When I think that it is only eighteen months since the Seed was first sown among you," he said, "I marvel at what the Lord hath wrought". (Achebe, 1958: pg 57-58)

The data finding 03 concludes the members of chistianity increases, there are children, women and men decides to become a converts and make a small grup of them. The existence of christianity increasingly accepted by the villagers. . In the religion activity the religious people not only at the level of relation with god but also includes relationships with the people (Esrofa , 2001)

\section{Establishment of Regulation}

The European has varies strategies colonialism in Africa, religious, langauge and the others implement new regulation. In their efforts to implement regulation in Africa. The

\section{British, Jurnal Bahasa dan Sastra Inggris}


impact of this new goverment makes the villagers have to follows their regulation as uses in their origin country England

Data 04:

"But apart from the church, the white men had also brought a government. They had built a court where the District Commissioner judged cases in ignorance. He had court messengers who brought men to him for trial". (Achebe 1958: pg 62)

"We have a court of law where we judge cases and administer justice just as it is done in my own country under a great queen". (Achebe, 1958: pg 69)

In the data 04 shows that the arrival of Europeans in Africa not only brough by religions but also new government which they uses in their origin countries who lead by a queen. European aims to guide the population alongside the regulation of indigenous to achieve the self-government status by create the best uses of elements in a society and respects by the population (Riyadi, 2016). In this case, the Britain uses their system of indirect rule which indirect rule policy concerns with the ruling of the people through their own people or traditional institutions with a close supervision from the British government.

Data 05:

"I have brought you here because you joined together to molest others, to burn people's houses and their place of worship. That must not happen in the dominion of our queen, the most powerful ruler in the world. I have decided that you will pay a fine of two hundred bags of cowries". (Achebe, 1958: pg 69)

In the data 05 describes the new rules and government under the commissioner district recieves the rejections from the six chiefs of Umuofia, they destroy the buildings where build by the white people. They must replace any destruction and they should pay a fine for the damage. In this case, before the white people come to Umuofia, Ibo society usually has their own low calls anchester's law. The villlagers can not easy to accept the new regualtion that European implement in Umuofia.

Data 06:

"You are not satisfied with your crime, but you must kill the white man on top of it." He carried a strong stick, and he hit each man a few blows on the head and back. Okonkwo was choked with hate. As soon as the six men were locked up". (Achebe, 1958: pg 69)

\section{British, Jurnal Bahasa dan Sastra Inggris}


"Okonkwo and his fellow prisoners were set free as soon as the fine was paid". (Achebe, 1958: pg 70)

Then for the data 06 shows the six chiefs of Umuofia not only pay the fine but also send into the prison by the intention to kills a court messagers, their plans hearing by the court messager and at the end they bring into the jail by the commissioner district. Colonialism could be impact in colonialization and after colonialization (Khapoya,2009). In this case the indiginous got the impact of civilization.

\section{The Contribution to The Development}

The contribution to develop african's society is one of the varies strategies in civilize Africa, Europeans build some places in support infrastructures in Africa. One of them establish a courthouse where a place to implement a new regulation in Umuofia.

Data 07 :

"The courthouse, like the church, was built a little way outside the village". (Achebe, 1958: pg 70)

$\ldots$

"But apart from the church, the white men had also brought a government. They had built a court where the District Commissioner judged cases in ignorance. He had court messengers who brought men to him for trial. Many of these messengers came from Umuru on the bank of the Great River, where the white men first came many years before and where they had built the centre of their religion and trade and government". (Achebe, 1958: pg 62)

The data findings 07 explains In the effort of European to develop infrastructures in Africa. One of them, a courthouse where a place to implement a new regulation in Umuofia, its regulation like what they use in their origin country England.

Data 08:

"New churches were established in the surrounding villages and a few schools with them" (Achebe, 1958: pg 64)

$\cdots$

"In the end Mr. Brown's arguments began to have an effect. More people came to learn in his school, and he encouraged them with gifts of singlets and towels. They were not all young, these people who came to learn. Some of them were thirty years old or more". (Achebe, 1958: pg 64)

...

"Mr. Brown begged and argued and prophesied. He said that the leaders of the land in the future would be men and women who had learned to read and write. If Umuofia failed to send her children to the school, strangers would come from other places to rule them". (Achebe, 1958: pg 64)

\section{British, Jurnal Bahasa dan Sastra Inggris}


In the 08 data it appears the white people not only brought by religion and a government in Umuofia but the white people also build schools to improve the education of the children becomes better, because the pastor argues that future leaders whose educated people. This is also not an easy thing, despite accepting rejection from parents of the students but at the end they allow their children to study in school where build by the priest. It is relate to Khapoya (2009: 135-136) in contribute to develops Africa society impact on rebellion by European colonialism colonialism

Data 09:

"Umuofia did not appear to have taken any special notice of the warrior's return. The clan had undergone such profound change during his exile that it was barely recognisable. The new religion and government and the trading stores were very much in the people's eyes and minds. There were still many who saw these new institutions as evil, but even they talked and thought about little else". (Achebe 1958: pg 64-65).

Moreover, for the finding data 09 shows Umuofia being calm after the commotion happens in Umofia, after build a school for education and and hospital for better health of African's society and another field by economical is build a markets or stores. In this case, most of Ibo society are a farmers, they can easy to sell their harvest. In colonialism is the policy or practice of acquiring full partial political control over another country, and exploitation in economical (Nwanosike, Oba.F and Onyije, 2011).

\section{Negative Impact of European colonialism in Africa}

It can be seen that the legacy of colonialism can have a positive but also negative impact. But on the other hand, the mechanics and systems uses by colonizers in a colony are inheritances that have a negative impact on people's lives both during colonialism and after colonialism where the habits or characteristics of the new colonial system will disappear for several years.

\section{Existence of Language}

The existence of European colonialism in Africa not only bring christianity as religion in Umuofia, indirectly they also bring a new language. In this case English as language they use in their origin country, they speak through the interpreter as their efforts to comunicate to the villagers. At the result, villagers difficult to understand.

Data 10:

"When they had all gathered, the white man began to speak to them. He spoke through an interpreter who was an Ibo man, though his dialect was different and

\section{British, Jurnal Bahasa dan Sastra Inggris}


harsh to the ears of Mbanta. Many people laughed at his dialect and the way he used words strangely". (Achebe 1958: pg 52)

$\cdots$

"Then the missionaries burst into song. It was one of those gay and rollicking tunes of evangelism which had the power of plucking at silent and dusty chords in the heart of an Ibo man. The interpreter explained each verse to the audience, some of whom now stood enthralled". (Achebe 1958: pg 53)

In the finding of data 10 shows Misionaries and villagers speaks through an interpreter, the differences of language and dialect between missionaries and villagers makes them difficulty undestand as well as communicate each other. The arrival of European in Africa inderectly brings new language in Umuofia, Nigeria Africa. Colonization brings to a (new) languages hierarchy in which the colonial language of the coloniser inscribes as the most prestigious language and come dominate the administrative structure and trade of each colony (Isabelle, 2007).

\section{CONCLUSION AND SUGGESION}

\section{Conclusion}

The arrival of European in Africa brings several impact such as : existence of Christianity in Umuofia, most of villagers decides to become a converts but directly Europeans also brings "English" as new language in Africa, the differences of language between European and Africans makes them difficulty understanding. Another strategies in colonize Africa, they not only practices religious but also implement regulation from their origin coutry "England" aims to guide the population alongside the regulation of indigenous to achieve the self-government status. Beside that, their contribution to development is another way to support the neccesity of Africa and to prosper them from the fields of health, economy and education.

European colonialism in africa brings a positive impact such as : Religious can be used as a spiritual basis for African society, build a school for education of Africans' children, hospital for a better healt of Africans' society as well as in economic field, European build a markets. But on the other hand, the mechanics and systems uses by European also brings a negative impact such as : language where European use english in colonialiasm that can impact to the langauge which exist in African.

\section{British, Jurnal Bahasa dan Sastra Inggris}




\section{Suggestion}

The researcher suggests for the ongoing researcher who wants to study this case total that they have to learn about the European colonialism in Africa. Especially to the students of English literature department, they are expected to find out and analyze other novel by using another impact of colonialism.

\section{REFERENCES}

Ratna, Nyoman Kute. 2003. Paradigma Sosiologi Sastra. Yogyakarta: Pustaka Pelajar.

Endraswara, Suwardi. 2008. Metode Penelitian Sastra. Yogyakarta:Medpress Esquire

Khapoya, Vincent B. (2009). The African experience. An introduction. New York: Longman

Blaxter, M. (1996, December). Criteria for the evaluation of qualitative research papers. Medical Sociology News, 22(1), 68-71

Damono, Sapardi Djoko. 2003. Sosiologi Sastra. Semarang: Magister Ilmu Susastra Undip.

Nugriyantoro, Burhan. 2009. Teori Pengkajian Fiksi. Yogyakarta : Gadjah Mada University Press.

Léglise, Isabelle and Migg, Bettina. Language and colonialism. Applied linguistics in the context of creole communities. Accesed from. https://halshs.archivesouvertes.fr. 21st August 2018.

Nwanosike, Oba.F. 2011 Colonialism and Education. Nigeria. 